Como citar: SILVA, Caíque Tomaz Leite da Silva. OLIVEIRA, Carlos Eduardo Sindona de. O Décimo Aniversário da Emenda 45 e a Posição Hierárquica dos Tratados de Direitos Humanos. Revista do Direito Público. Londrina, v.11, n.1, p.137-162, jan/abr.2016. DOI: $10.5433 / 1980-511 X .2016$ v11n1p137. ISSN: 1980-511X.

* Doutorando em Direito Público (fase de dissertação) e Pós-Graduado em Direitos Humanos pela Universidade de Coimbra (POR). E-mail: caique.thomaz@hotmail.com

** Investigador bolsista do grupo de pesquisa "Estado, Direito e Sociedade", do Centro Universitário Toledo, coordenado pelo Professor Caíque Tomaz Leite da Silva. E-mail: cadu_95@hotmail.com

\section{O Décimo Aniversário da Emenda 45 e a Posição Hierárquica dos Tratados de Direitos Humanos}

\author{
The Tenth AnNiversary of the 45 Amendment \\ and Hierarchical Position of Human Rights \\ TREATIES \\ * Caíque Tomaz Leite da Silva \\ ** Carlos Eduardo Sindona de Oliveira
}

Resumo: no dia 8 de dezembro de 2004, as Mesas da Câmara dos Deputados e do Senado Federal promulgaram a Emenda Constitucional 45, que realizou uma grande reforma no poder judiciário. O texto propõe uma releitura daquela Emenda por ocasião da celebração de seu decênio, repristinando o debate sobre a hierarquia constitucional dos tratados de direitos humanos no ordenamento do jurídico pátrio, através da análise dos parágrafos do art. $5^{\circ}$ da Constituição e dos interesses dos constituintes reformadores que introduziram-nos na Carta Política.

Palavras-chave: Direito Constitucional. Direito Internacional dos Direitos Humanos. Processo Legislativo. Hierarquia. Emenda Constitucional 45/2004.

Abstract: on December $8^{\text {th }}$, 2004, Brazilian's House of Representatives and Senate promulgated the Forty-fifth Brazilian Constitutional Amendment that brought changes on the Judiciary. This essay proposes a rereading of that Amendment in its $10^{\text {th }}$ anniversary, reopening and making deeper the debate about the constitutional hierarchy of the human rights treaties in Brazilian law, through analysis of the paragraphs of the $5^{\text {th }}$ article of the Constitution and of the original intentions of reformers constituents on introducing them to it.

Keywords: Constitutional Law. International Human Rights Law. Legislative Process. Hierarchy. Forty-fifth Brazilian Constitutional Amendment. 


\section{INTRODUÇÃO}

Decorrida a primeira década da promulgação da EC 45/04, o alcance prático-teórico da grande Reforma do Judiciário ainda é uma grande incógnita seja para os estudiosos da Teoria da Constituição, seja também para os cidadãos que esperam ainda ver concretizado o sonho de acesso pleno e eficácia da Justiça.

Uma dessas muitas interrogações pendentes é sem dúvida a intrincada interação entre o Direito Constitucional e o Direito Internacional dos Direitos Humanos que a citada Emenda estabeleceu ao promulgar os $\S \S 3^{\circ}$ e $4^{\circ}$ ao art. $5^{\circ}$ da Constituição. Recorrendo à história, à hermenêutica, à deôntica $\mathrm{e}$ à teleologia, este ensaio tem o intento de encontrar uma solução para a hierarquia normativa dos tratados de direitos humanos que esteja de acordo com o espírito do tempo presente despacializado e globalizado (GALLEGO, 2006, p. 884).

Delimitado objetivamente o problema, buscaremos a extensão das razões históricas que levaram à promulgação da Emenda $45 \mathrm{e}$ a inclusão dos $\S \S 3^{\circ} \mathrm{e} 4^{\circ}$ ao art. $5^{\circ}$ da Constituição Republicana, enfocando nas mudanças práticas que a nova sistemática criou. Investigaremos também a hierarquia do Decreto Legislativo 186/08 que deu à Convenção sobre os Direitos das Pessoas com Deficiência e seu Protocolo Facultativo a equivalência de Emenda Constitucional via $\S 3^{\circ}$, e do Estatuto de Roma que criou o Tribunal Penal Internacional ao qual a Constituição promete obediência no $\S 4^{\circ}$.

As referências teóricas do ensaio são a exigência de se recorrer a fontes primárias de documetos da época como o Diário do Congresso no contexto da Reforma do Judiciário, e a necessidade de se buscar uma comunhão e interconectividade entre a Carta Política e as Convenções de Direitos Humanos, superando o paradigma de soberania seja do direito interno, seja do direito internacional.

Como se vê, o ponto de vista que ora se enfoca transcende a problemática entre Estado e comunidade internacional, pois envolve a autolimitação da soberania do estado vis-à-vis a concessão de direitos subjetivos (JELLINEK, 1905, p. 134), e parece-nos que a visão do status quaestiones pode oferecer uma eminente contribuição para oferecer uma interpretação que não descarte seja a Carta Magna nacional sejam os diplomas internacionais.

A busca pela convergência, há de se convir, é o caminho aparentemente mais coerente, porquanto se houver uma possibilidade de que essas normas 
coexistam, quem sairão vitoriosas serão as pessoas que estarão melhormente protegidas pelos dois escudos normativos.

\section{A EMENDA CONSTITUCIONAL 45 E OS TRATADOS DE DIREITOS HUMANOS}

\subsection{A História da PEC 96/92}

A gênese da Emenda 45 se encontra na Proposta de Emenda à Constituição 96/92 ${ }^{1}$, apresentada originalmente pelo então deputado federal Hélio Bicudo do PT/SP. A proposta original pugnava por mudanças nos artigos 93, 94, $95,101,102,104,105,107,111,112,113,115,122,123,124,125$ e 128 da Carta Maior. Analisando este dado com a estruturação da Constituição tal qual era no dia 5 de outubro de 1988, vemos que a referida PEC propunha uma alteração em praticamente todos os artigos do Capítulo III do Título IV da Lex Majoris, o que significaria, portanto, mudanças em quase toda a estrutura constitucional até então vigente do Poder Judiciário ${ }^{2}$. $\mathrm{Na}$ justificativa apresentada pelo Deputado Federal na apresentação da proposta, evidente fica o desejo de modernização do aparelhamento do Judiciário através daquela iniciativa:

A timidez com que o governo brasileiro vem atendendo à necessidade de modernização do nosso aparelhamento judiciário tem sido, sem dúvida, a causa da crise avassaladora, em que há muitos anos se esbate a nossa Justiça. [...] Ora, a administração da justiça é problema que a todos interessa. Não basta que o Legislativo elabore as leis e o Executivo as sancione. É preciso que o Judiciário assegure a sua execução no caso concreto. [...] Daí, naturalmente, desde há muito falar-se e com insistência de ampla reforma do Poder Judiciário que abranja desde as pequenas comarcas do interior até o Supremo Tribunal Federal. (BRASIL, 1992)

Portanto, muito mais do que um esforço de "extração do significado" dos dispositivos que a Emenda veio a trazer à Carta Política, é necessário se ter

\footnotetext{
Não é raro ver na doutrina (MAZZUOLI, 2005, p. 307) ou até mesmo na jurisprudência (BRASIL, 2008 , p. 43) a errônea informação de que a proposta que gerou a EC 45 foi a PEC 29/2000. Na verdade, o que acontece é que esta numeração foi dada quando da tramitação da PEC 96/1992 no Senado Federal. Todavia, como a casa iniciadora desta proposta de emenda foi a Câmara dos Deputados, não há razão em aludir àquela iniciativa pela numeração dada no Senado.

2 A PEC 96/92 foi apresentada pouco tempo depois da promulgação da constituição, antecedendo mesmo a Revisão Constitucional prevista no art. $3^{\circ}$ do ADCT, razão pela qual a Emenda 45 poderia ter se tornado uma Emenda Constitucional de Revisão.
} 
em mente os interesses legislativos que orientaram a apresentação da proposta, a saber, uma reforma do Judiciário desde os magistrados de primeira instância e das instituições que os cercavam até os mais altos cargos daquele Poder, bem como a ampliação da sua área de atuação na distribuição da justiça ${ }^{3}$.

Inicialmente, a Comissão de Constituição e Justiça da Câmara dos Deputados, através do parecer do relator da matéria, o Deputado Luiz Carlos Santos, posicionou-se favoravelmente à admissibilidade da proposta, tendo encaminhando-a para Câmara Revisional do ano seguinte, em 1993; todavia, durante a Revisão Constitucional, a PEC não foi debatida, tendo sida considerada prejudicada por esse motivo (BRASIL, 1994), o que acarretou o seu primeiro arquivamento.

No entanto, através de um procedimento regimental, o Deputado Bicudo e seus apoiadores conseguiram que ela voltasse à discussão na Casa iniciadora, o que proporcionou à presidência da Câmara, a criação da primeira Comissão Especial $^{4}$ que discutiria exclusivamente a problemática objeto da PEC 96/92. A relatoria da Comissão foi inicialmente dada ao Deputado Jairo Carneiro, e durante um ano não houve consenso entre os parlamentares sobre a demanda, o que mais uma vez acarretou o arquivamento da PEC conforme mandava o Regimento Interno (caso do art. 105, caput).

Somente após o segundo arquivamento houve um real interesse político por parte dos congressistas em trabalhar conjuntamente para superar as divergências pessoais para aprovar a Emenda que prometia ajudar a solucionar os inúmeros problemas do Judiciário. Assim, a matéria passou às mãos do Deputado Aloysio Nunes, tendo depois, enfim, chegado à sua última relatoria, designada para a Deputada Zulaiê Cobra Ribeiro, ambos do PSDB/SP.

\footnotetext{
3 Segundo a antiguíssima e ainda acertada lição de Aristóteles e de Santo Tomás de Aquino, a justiça que o Estado presta aos cidadãos (denominada de justiça distributiva), é na verdade uma subespécie de justiça, antagônica àquela chamada justiça comutativa (entre particulares). São palavras do Doutor Angélico: "[...] a justiça particular se ordena a uma pessoa privada que está para a comunidade como a parte para o todo [...]. A outra relação é do todo às partes; a ela se assemelha a relação entre o que é comum e cada uma das pessoas. A essa segunda relação se refere a justiça distributiva, que reparte o que é comum de maneira proporcional". (AQUINO, 2005, pp. 97-98 [Suma Teológica IIII, q. 61, a. 1, rep]). Justamente por seu caráter reparticionista, a justiça distributiva tem por escopo a tutela do bem comum, objetivo primário das instituições jurídicas.

${ }^{4} \mathrm{O}$ art. 202 do Regimento Interno da Câmara dos Deputados trata do procedimento legislativo das Propostas de Emenda à Constituição que passam pela Casa: "A proposta de emenda à Constituição será despachada pelo Presidente da Câmara à Comissão de Constituição e Justiça e de Cidadania, que se pronunciará sobre sua admissibilidade, no prazo de cinco sessões, devolvendo-a à Mesa com o respectivo parecer". §2。: "Admitida a proposta, o Presidente designará Comissão Especial para o exame do mérito da proposição, a qual terá o prazo de quarenta sessões a partir de sua constituição
} 
Os trabalhos da Comissão Especial chefiada pela Deputada Zulaiê são de acentuada importância para a interpretação histórica, haja vista que foi justamente nela que se introduziu no corpo do projeto, o $\S 3^{\circ}$, do art. $5^{\circ}$, da Constituição. Já o texto do hoje $\S 4^{\circ}$ do mesmo artigo ${ }^{5}$, sublinha-se, foi incorporado pela Emenda Aglutinativa $n^{\circ}$ 20, durante a votação da PEC em primeiro turno na Câmara, que aconteceu no dia 5 de abril de 2000 (BRASIL, 2014) ${ }^{6}$.

\subsection{O Problema de Interpretação do Art. $5^{\circ}, \S^{\circ}$, da CF}

Foi neste contexto de "reforma do Judiciário" que a interação normativa entre direito constitucional e direito internacional dos direitos humanos se deu no contexto normativo constitucional, face ao problema interpretativo que se via (e perdura) da posição hierárquica dos tratados internacionais de direitos humanos na ordem normativa interna. Toda a problemática relativa a este tema tinha como vértice a interpretação do art. $5^{\circ}$, $2^{\circ}$, da Carta Magna, verbis: "Os direitos e garantias expressos nesta Constituição não excluem outros decorrentes do regime e dos princípios por ela adotados, ou dos tratados internacionais em que a República Federativa do Brasil seja parte".

Forçoso é reconhecer, a priori, a falibilidade da exegese estritamente gramatical em aberta afronta a teleologia do dispositivo, motivo maior da extraordinária dificuldade da doutrina em encontrar um ponto convergência quanto à interpretação dele. Num cenário incerto, inevitável seria a propagação de diversas vertentes interpretativas, que muito mais do que respostas jurídicas, ofereciam e oferecem, ainda hoje, soluções baseadas num universo ideológico fundamentalista. Vejamos as mais expressivas.

A primeira é representada por Celso Albuquerque MELLO (1999, p. 27), que defende a supraconstitucionalidade dos tratados: em um hipotético conflito entre a regra interna com a internacional, simplesmente invalida-se a primeira e se faz aplicar à segunda. Sobre isso, explica EMERIQUE e GUERRA (2008, p. 5):

${ }^{5}$ Dizemos "o texto do hoje $\S 4^{0}$ " porque ele não ia ser posicionado onde se encontra atualmente na Constituição. A Emenda Aglutinativa 20 pugnava pela inserção do texto como $\S 6^{\circ}$ no art.109 da Constituição. Contudo, quando da discussão da PEC no Senado, houve uma realocação do texto para sua posição atual.

${ }^{6}$ Esta informação, bem como à que nos referíamos na nota de rodapé anterior, foi obtida através da Ouvidoria Parlamentar da Câmara dos Deputados, que se comunicou conosco no dia 7 de agosto de 2014 por via eletrônica. 
Quando o critério consagra a supremacia do direito interno, este é incompatível com a principiologia do Direito Internacional Público. [...] Ou seja, a partir do momento que o Estado se submete às normas internacionais e venha a descumprí-las estaria praticando um ato ilícito e, portanto, sujeito a uma reparação internacional.

Em verdade, os supraconstitucionalistas não distinguem em absoluto a espécie do tratado: o pacto internacional tem caráter erga omnes, independentemente se este acordo é sobre direitos humanos, ou sobre qualquer outro assunto. O background ideológico da magnitude supraconstitucional dos tratados internacionais encontra amparo jurídico normativo em inúmeros tratados internacionais assinados pelo Brasil, como a Convenção de Viena sobre Direito dos Tratados; e em inúmeras decisões proferidas por Tribunais Internacionais ${ }^{7}$. O fundamento de sua sustentação teorética reside no princípio da voluntariedade que orientaria um direito internacional realista. Nos tratados de direitos humanos, contudo, a fundamentação nunca é tão singela, e princípios como a voluntariedade e reciprocidade são constantemente desafiados.

Nesse sentido, seria da própria essência do direito internacional a necessidade de autonomia vis-à-vis o direito constitucional, não se admitindo, in abstrato, escusas que qualquer estado sustentasse para descumprir os compromissos internacionais sob a ótica contratualista do "pacta sunt servanda", expressamente consagrado na Convenção de Viena. Isso independentemente da discussão atinente à vinculação a acordos multilaterais universais, sem expressa ratificação, como a Declaração Universal dos Direitos Humanos $^{8}$; e a vinculação aos costumes internacionais, mesmo que em afronta aos costumes do estado em causa.

A falência, contudo, dessa interpetação, deriva da rigidez e da estrutura que as Constituições das nações esposam. Como podemos conciliar a tese

Casos Barcelona Traction (segunda fase). ICJ Reports, 1970, $\S 33$ e 34; e United States Diplomatic and Consular Staff in Tehran. ICJ Reports, 1980, § 91.

8 Aduz John Peters HUMPHREY (1979, p. 33): "the Declaration is now part of the law of nations and therefore binding on all states whether they voted for it or not, this is not because it was adopted by the Assembly, important as that may have been, but for other reasons including subsequent events and the emergence of a juridical consensus evidenced by the practice of states that the Declaration is now, whatever the intention of its authors may have been in 1948, binding as part of the law of nations". No mesmo sentido se manifestou o Secretário-Geral da ONU: "the Declaration not only constitutes an authoritative interpretation of the Charter obligations but also a binding instrument in its own right, representing the consensus of the international community on the human rights which each of its members must respect, promote and observe." (UN Doc. A/ 720/Add.1, 1968, p. 13) 
supraconstitucionalista com o que diz, por exemplo, o art. 102, III, "b", CF, o qual legitima o STF a declarar a "inconstitucionalidade de tratado"? Mais: o que dizer da competência exclusiva do Congresso Nacional de decidir em último sobre os tratados (art. 49, I)? Como crer ser possível que por si só o direito internacional previsto nos tratados é vigente e hierarquicamente superior se existe expresso comando constitucional que enseja a participação do Parlamento como condição de aplicabilidade, no âmbito interno, dos pactos internacionais? Em razão disso, hoje a tese da supraconstitucionalidade é amplamente minoritária.

A segunda via interpretativa é aquela que era consagrada em grande parte da doutrina constitucionalista antes da EC 45, e na pretérita jurisprudência do $\mathrm{STF}^{9}$, que defendiam o princípio absoluto da supremacia da Constituição firmado na soberania ${ }^{10}$ popular do Estado de Direito Brasileiro, evidenciado pela rigidez da Constituição. Argumentavam que, em relação ao $\S 2^{\circ}$, do art. $5^{\circ}$, teleológica e sistematicamente, a intenção do constituinte originário era tãosomente impedir que o rol da nossa Carta de Direitos pudesse ser interpretado como taxativo às hipóteses que figuram no art. $5^{\text {o11 }}$.

Levado a cabo este raciocínio, todas as normas internacionais de direitos humanos presentes nos tratados internacionais seriam consideradas normas infraconstitucionais ordinárias, não havendo espaço para segundas ou terceiras interpretações para o problema. Advogando nesta seara, Alexandre de MORAES (2011, p. 414) utiliza o exemplo do ocorrido na ADIn 939-7/DF, em que o Supremo entendeu ser a anterioridade tributária cláusula pétrea, mesmo

\footnotetext{
9 À título demonstrativo: HC 72.131-1/RJ, j. 23.11.1995.

${ }^{10}$ Para os internacionalistas, falar ainda hoje em soberania tal como a modernidade a definiu, é uma excrescência e uma mentira. MAZZUOLI (2005, pp. 313-314, grifamos), ao comentar a inclusão do $\S 3^{\circ}$, ao art. $5^{\circ}$, pela EC 45 foi taxativo: "Além de demonstrar total desconhecimento do direito internacional público, notadamente das regras basilares da Convenção de Viena sobre o Direito dos Tratados, em especial as de jus cogens, traz o velho e arraigado ranço da já ultrapassada noção de soberania absoluta". Já para os constitucionalistas, ela é uma realidade própria do direito, sendo uma questão da ontologia do ius, a necessidade da soberania. Nesse sentido, patente é a doutrina de Miguel REALE (2000, p. 109): "O bem comum é o fundamento último do Direito assim como o é da soberania, desde que por bem comum se entenda a 'ordem social justa'. A compreensão da natureza do poder torna-se mais clara quando lembramos que o bem comum não coincide com a idéia particular que cada homem faz de seu próprio bem [...]. Sem a soberania não estaria assegurada a realização do bem comum ou a justiça social".

${ }^{11}$ Essa tese, porém, é historicamente inverídica, pois o texto do $\S 2^{\circ}$ foi proposto por Antônio Augusto Cançado Trindade, na audiência pública de 29 de abril de 1987, (BRASIL, 2008, p. 52), com a intenção de favorecer a corrente internacionalista. Entretanto, ainda que a inclusão do referido parágrafo tenha uma origem de cunho internacionalista, ela não consegue responder à objeção da rigidez constitucional que sempre foi o argumento mais forte dos constitucionalistas: a interpretação dos constitucionalistas é (ou era) mais sistemática do que a dos internacionalistas.
} 
não estando descrita no rol do art. $5^{\circ}$. O constitucionalista explica que naquele caso teria ocorrido uma situação simétrica àquela albergada pelo $\S 2^{\circ}$, do art. $5^{\circ}$, em que uma norma alheia à enumeração de direitos foi considerada como um direito não passível de exclusão (cláusula pétrea).

Em suma, ao enumerar os argumentos dos constitucionalistas, tínhamos: 1) a rigidez constitucional (art. $60, \S 2^{\circ}$ ), ou seja, sem a maioria qualificada das duas votações de $3 / 5$ em ambas as Casas se estaria usurpando o poder exclusivo do Congresso de modificar a Carta Magna; 2) a autorização dada ao Supremo Tribunal Federal de "declarar a inconstitucionalidade de tratado" 12 (art. 102, III, "b"); 3) um problema de processo legislativo, sistematizado em dois argumentos: a) o procedimento legislativo sobre tratados ${ }^{13}$ já estar previsto na Constituição (art. 49, I) sem qualquer distinção entre um tratado de direitos humanos e outro comum; e b) a ideia de que um decreto legislativo ${ }^{14}$ possa "reformar" (stricto sensu) a Constituição.

Por outro viés, a doutrina internacionalista argumenta que esta visão fundamentalista dos constitucionalistas faz "letra morta" do $\S 2^{\circ}$ (VICENTE SOBRINHO, 2013, p. 55). Assim, estes autores levantaram a tese da constitucionalidade material dos tratados internacionais de direitos humanos, tendo como porta-vozes, Flávia PIOVESAN (2006, pp. 29-30) e Valério de Oliveira MAZZUOLI (2005, pp. 305-306, grifos no original):

E a nossa interpretação sempre foi a seguinte: se a Constituição estabelece que os direitos e garantias nela elencados "não excluem" outros provenientes dos tratados internacionais em que a República Federativa do Brasil seja parte, é porque ela própria está a autorizar que esses direitos e garantias internacionais constantes dos tratados internacionais de direitos humanos e ratificados pelo Brasil "se incluem" no nosso ordenamento jurídico interno, passando a ser considerados como se na Constituição estivessem. [...] Para nós, a cláusula aberta do $\S 2^{\circ}$ do art. $5^{\circ}$ da Carta de 1988 , sempre admitiu o ingresso dos tratados internacionais de proteção aos direitos humanos no mesmo grau hierárquico das normas constitucionais, e não em outro âmbito de hierarquia normativa.

\footnotetext{
${ }^{12}$ A dicção do legislador é infeliz. Não é que a Corte Suprema possa declarar inconstitucional um tratado: ela pode declarar não constitucional o Decreto Legislativo que o incorpora ou o Decreto Presidencial que o promulga, seja por razões formais ou materiais que afrontam a Constituição.

13 “. [...] uma vez adotado o texto definitivo do tratado pelos plenipotenciários do governo brasileiro, a sua conclusão definitiva vai depender da apreciação do Congresso Nacional no âmbito de um processo legislativo denominado pela doutrina de incorporação ou internalização." (BICHARA, 2013, p. 79, grifos no original).

${ }^{14}$ A espécie legislativa com que o Congresso incorpora um tratado ao ordenamento.
} 
Assim, para os internacionalistas, o $\S 2^{\circ}$ daria a cada um daqueles direitos previstos nos tratados, um status de constitucionalidade substancial (material). Firmados nesta premissa, a doutrina internacionalista brasileira começou a utilizar para o direito pátrio a famosa expressão francesa do bloc de constitutionnalité que, segundo VARGAS (2007, p. 13), pode ser definido como "um conjunto de normas constitucionais consideradas em sua unidade" 15 . No entanto, a tese da constitucionalidade material dos tratados não oferecia soluções para às objeções dos constitucionalistas. A dificuldade de se falar em bloco de constitucionalidade no ordenamento vigente, era a expressa existência de diferenciação de tratamento entre as normas constitucionais e as normas infraconstitucionais. Reiteramos: como seria possível falar em normas de natureza constitucional (como queriam os internacionalistas), se o tratamento expresso para tais dispositivos era de natureza infraconstitucional? ${ }^{16}$

Com efeito, a hegemonia da jurisprudência ditava que a Constituição não apontava claramente, até a Emenda 45, para uma classificação real e efetiva dos tratados de direitos humanos como normas de um "bloco de constitucionalidade" aos quais estaria o direito brasileiro obrigado a observar.

Em atenção a tal circunstância, o então Ministro Presidente do STF, Celso de Mello, famoso defensor da causa internacionalista, enviou uma sugestão à Comissão Especial chefiada pela Deputada Zulaiê Cobra Ribeiro, para que se incluísse um $\S 3^{\circ}$, ao art. $5^{\circ}$, da $\mathrm{CF}^{17}$, no intuito de reformar esta visão da jurisprudência dominante:

\footnotetext{
${ }^{15}$ Em "termos matemáticos" teríamos o seguinte: Normas constitucionais $=C F / 88+$ bloco de constitucionalidade (tratados de direitos humanos). A única diferença entre o bloco e a Constituição mesma, seria o fato do bloco não ter a aparência de norma constitucional, mesmo ele já o sendo materialmente.

${ }^{16}$ Explicamos: caso se aceitasse a tese da constitucionalidade material dos tratados, isso nada alteraria no mundo fático, porquanto a supremacia da Constituição e o tratamento infraconstitucional para com os tratados ainda assim seria obedecido. Não se estaria, portanto, fazendo valer a equiparação tal qual argumentavam os internacionalistas.

${ }^{17}$ Valério MAZZUOLI (2005, p. 313), muito antes da promulgação da EC 45, já tinha sugerido uma introdução de um $\S 3^{\circ}$, ao art. $5^{\circ}$, que clarificasse a tese internacionalista: "Os tratados internacionais referidos pelo parágrafo anterior, uma vez ratificados, incorporam-se automaticamente na ordem interna brasileira com hierarquia constitucional, prevalecendo, no que forem suas disposições mais benéficas ao ser humano, às normas estabelecidas por esta Constituição”. Com a devida vênia, cremos que tal dispositivo poderia ser declarado inconstitucional caso viesse a ser adotado, já que ele desmontaria a rigidez da Constituição (art. $60, \S 2^{\circ}$ ), limitação estabelecida pelo poder constituinte originário. Sem embargo, sublinhamos que nem sempre no caso prático haveria de ser claro se o que está disposto no tratado, efetivamente, é "mais benéfico ao ser humano".
}

Revista do Direito Público, Londrina, v.11, n.1, p.137-162, jan./abr.2016 | DOI: 10.5433/1980-511X.2016v11n1p137 
Buscando a efetividade da prestação jurisdicional, acolhemos também sugestão do Ministro Celso de Mello, Presidente do Supremo Tribunal Federal, no sentido da outorga explícita de hierarquia constitucional aos tratados celebrados pelo Brasil, em matéria de direitos humanos, à semelhança do que estabelece a constituição argentina (1853), com a reforma de 1994 (art. $\left.75, n^{\circ} 22\right)$, introdução esta no texto constitucional que afastará a discussão em torno do alcance do art. $5^{\circ}$, $2^{\circ}$. (RIBEIRO, 1999, apud BRASIL, 2014, grifamos).

Antes de adentramos no debate sobre a inclusão do $\S 3^{\circ}$, ressalta-se, em linhas nada rigorosas, a ideologia por detrás da tutela de direitos subjetivos pelos direitos fundamentais, inseridos nas constituições; e pelos direitos humanos, denominação empregada pelo direito internacional, em seu âmbito de regulamentação normativa, doutrinária e jurisprudencial.

René SÈVE (1997, p. 29) lembra-nos que "Il est clair que la doctrine des droits de l'homme décline l'idée de dignité individuelle quis'attache à tout individu et qui s'exprime sur le plan juridique par un certain nombre de prérogatives", ou seja: a ideia-gênese da outorga de direitos oponíveis ao estado está fundada, antes de mais, na dignidade do ser humano, e somente se o vértice da equação estiver fixado nela é que qualquer argumento poderá ser levado a sério.

Com efeito, notar a inclusão do $§ 3{ }^{\circ}$ no art. $5^{\circ}$, é, antes de mais, louvável, pois:

É alentador que as conquistas do direito internacional em favor da proteção do ser humano venham a projetar-se no direito constitucional, enriquecendoo e demonstrando que a busca de proteção cada vez mais eficaz da pessoa humana encontra guarida nas raízes do pensamento tanto internacional quanto constitucional. (TRINDADE, 1996, p. 21-22).

Robert ALEXY (2014, p. 111), por sua vez, é igualmente feliz ao afirmar que "os direitos humanos, enquanto direitos morais, não só não podem ter sua força invalidada por normas jurídico-positivas mas são também o padrão com o qual se deve medir toda a interpretação daquilo que está positivado". Essa característica especial dos direitos humanos, acolhida tanto pelo constitucionalismo quanto pelo internacionalismo atuais, parece prover a caminhada de convergência entre ambas as matérias, denominada por Caíque Tomaz Leite da SILVA (2011, p. 39) de constitucionalismo sincrético, um 
constitucionalismo que não se esgota no exercício da soberania ${ }^{18}$, mas que dá nova vida e consciência para ela:

O movimento juspublicístico que constitui o novo espaço público assiste ao renascimento de um 'constitucionalismo global convergente ou constitucionalismo sincrético', onde são cada vez mais nítidos e sistemáticos movimentos de expansão do direito internacional dos direitos humanos e a contracção da cláusula de reserva de soberania, que atenua progressivamente a dicotomia entre direito constitucional e direito internacional.

Sublinhada tal premissa interpretativa, delimita-se os contornos de uma reta exegese do disposto no art. $5^{\circ}, \S 3^{\circ}$, a qual, como se sabe, deve ser sempre teleológica. A codificação das regras tem como pressuposto lógico, portanto, uma relação de previsibilidade atestada na fórmula "se - então" (ÁVILA, 2012, p. 49) entre o interesse originário do legislador e a realização prática dos acontecimentos previstos.

No caso da concreta intensão e aplicação do $\S 3^{\circ}$, somos conduzidos a compreensão de que o interesse originário do constituinte reformador era peremptoriamente superar as objeções dos constitucionalistas atinentes a rigidez constitucional e processo legislativo, bem como deixar explícito um tratamento diferenciado para as normas de direito internacional dos direitos humanos. Além disso, a citação expressa de um modelo especifico inspirador da nova regra é mais um dado a ser considerado, pois a primeira se torna a referência de interpretação também para a segunda, através do que se convencionou chamar de interpretação comparativa ${ }^{19}$.

Com efeito, vejamos o que diz a Constituição Argentina no citado art. 75 e seu $n^{\circ} 22$ :

Articulo $75^{\circ}$ - Corresponde al Congreso:

${ }^{18}$ Como se vê, o debate quanto ao papel da soberania não se esgota. Os constitucionalistas objetam que todo e qualquer compromisso internacional firmado pelos Estados, ao ser obedecido por eles, longe de ser uma restrição ao direito de soberania, seria um exemplo de exercício dela, pois o estado somente obedeceria "se quisesse" aquele acordo, tendo em vista que uma Corte Internacional não poderia impor na prática decisões de cunho absolutamente jurídico, desvinculadas de sanções econômicas ou retaliações diplomáticas. Em decorrência disto, HART (2012, p. 276 e 277) se pergunta se o direito internacional seria de fato uma matéria do direito.

19 António Enrique Pérez LUÑO (2012, pp. 16-17) recorda que a estrutura normativa das diversas constituições segue a cultura jurídica do seu tempo. Ora, apesar das muitas diferenças históricoevolutivas entre o constitucionalismo brasileiro e o constitucionalismo argentino, o fato dos constituintes derivados brasileiros expressamente se inspirarem na realidade da nação vizinha faz com que de fato haja uma fecundidade notável de um sistema para o outro.

Revista do Direito Público, Londrina, v.11, n.1, p.137-162, jan./abr.2016 | DOI: 10.5433/1980-511X.2016v11n1p137 
$\mathrm{N}^{\mathrm{o}}$ 22. Aprobar o desechar tratados concluidos con las demás naciones y con las organizaciones internacionales y lós concordatos con la Santa Sede. Los tratados y concordatos tienen jerarquia superior a las leyes.

La Declaración Americana de los Derechos y Deberes del Hombre; la Declaración Universal de Derechos Humanos; La Convención Americana sobre Derechos Humanos; el Pacto Internacional de Derechos Economicos, Sociales y Culturales; el Pacto Internacional de Derechos Civiles y Politicos y su Protocolo Facultativo; la Convención sobre la Prevención y la Sanción del Delito de Genocidio; la Convención Internacional sobre la Eliminación de todas las Formas de Discriminación Racial; la Convención sobre la Eliminación de todas las Formas de Discriminación contra la Mujer; la Convención contra la Tortura y otros Tratos o Penas Crueles, Inhumanos o Degradantes; la Convención sobre los Derechos del Niño; en las condiciones de su vigencia, tienen jerarquia constitucional, no derogan artículo alguno de la primera parte de esta Constitución y deben entenderse complementarios de los derechos y garantias por ella reconocidos. Sólo podran ser denunciados, en su caso, por el Poder Ejecutivo nacional, previa aprobación de las dos terceras partes de la totalidad de los miembros de cada Cámara.

Los demás tratados y convenciones sobre derechos humanos, luego de ser aprobados por el Congreso, requeriran del voto de las dos terceras partes de la totalidad de los miembros de cada Cámara para gozar de la jerarquia constitucional.

A primeira vista, da simples e desatenta leitura do dispositivo modelo, aduz-se justamente a tese que hoje é adotada pelo Supremo Tribunal Federal, a qual, como se verá, não deixa de ser duramente criticada: a tese da supralegalidade dos tratados aprovados antes da EC 45/04 (existiria ainda a supremacia da Constituição e os tratados ainda são entendidos como normas infraconstitucionais, embora não sejam normas infraconstitucionais ordinárias).

Entretanto, o $\mathrm{n}^{\mathrm{o}} 22$, do art. 75, da Lex Majoris Argentina, há três tratamentos diferentes no tocante aos tratados que a República Argentina assina: os tratados de natureza supralegal que não têm por objeto matéria de direitos humanos (independentemente de "quando" foram assinados), os tratados de direitos humanos anteriores à Reforma Constitucional de 1994, que já tinham sido assinados e estavam em vigor como normas de natureza não constitucional, e os tratados de direitos humanos posteriores à $\mathrm{RF} / 94$, os quais poderiam se tornar normas constitucionais desde que aprovados com $2 / 3$ dos votos das Casas Legislativas (quórum das emendas). 
Isso posto, avancemos sobre o $\S 3^{\circ}$, em simetria ao percurso estabelecido pelo constituinte argentino percorrendo a sua redação, sua obrigatoriedade ou não em relação às convenções de direitos humanos posteriores à $\mathrm{EC} 45$, o status normativo dos tratados anteriores à EC 45/04, se há algum tratado que a emenda tenha elevado ao status de norma constitucional, e a hierarquia das convenções aprovadas pelo rito de emenda.

Quanto à redação. Ora, se era intenção do constituinte reformador introduzir uma fórmula que conciliasse rigidez constitucional, processo legislativo e primazia do ser pessoa neste cenário de reforma do Judiciário, deve-se prestigiar a redação do dispositivo: "Os tratados e convenções internacionais sobre direitos humanos que forem aprovados, em cada Casa do Congresso Nacional, em dois turnos, por três quintos dos votos dos respectivos membros, serão equivalentes às emendas constitucionais" ${ }^{20}$.

Quanto à obrigatoriedade do rito para os tratados posteriores. A Constituição Federal prevê, em seu art. $4^{\circ}$, II, que nas relações internacionais, o Brasil se regerá pela prevalência dos direitos humanos. Ora, se deve ser assim nas relações interestatais, o deve ser também nas relação internas, de modo que a outorga de status de emenda às convenções futuras não parece ser decisão discricionária do Congresso em uma interpretação sistemática da Constituição, uma vez que se alcance o quórum a que se refere o dispositivo supracitado $^{21}$.

Convenções sobre direitos humanos anteriores à EC 45. O caso específico do depositário Infiel (art. 5º LXVII, da CF e art. $7^{\circ}, n^{\circ} 7$, da Convenção Americana de Direitos Humanos) ${ }^{22}$ que culminou com a edição da Súmula Vinculante 25, foi o mais famoso e controvertido exemplo desse aspecto envolvendo o art. $5^{\circ}, \S 3^{\circ}$.

\footnotetext{
${ }^{20}$ Vê-se que não se pode agora dizer não ser explícito na Constituição um tratamento diferenciado aos tratados de direitos humanos relativamente aos tratados que tenham por objeto outros assuntos, bem como se mantém a rigidez constitucional ao exigir dos primeiros o mesmo quórum exigido para as emendas constitucionais; não obstante, críticas à redação do dispositivo não faltam, pois diferentemente do caso argentino, a norma brasileira não foi analítica quanto ao tempo em que o tratado foi incorporado.

${ }^{21}$ Não obstante, já houve alguns tratados de direitos humanos que foram internalizados após a EC 45 sem o procedimento de Emenda. É o caso, por exemplo, do Decreto Legislativo 661/10, o qual promulgou a Convenção Internacional para a Proteção de Todas as Pessoas Contra o Desaparecimento Forçado.

22 "A questão se torna complexa porque, a depender de como se vê a posição do tratado dentro da estrutura normativa do ordenamento jurídico brasileiro, pode-se dizer que, no Brasil a prisão do depositário infiel é legal ou que não é”. (SIMON, 2013, p. 103).
} 
O Ministro Gilmar Ferreira Mendes (BRASIL, 2008, p. 43, grifos originais) foi o primeiro que sustentou a tese de que com a inclusão do $\S 3^{\circ}, o$ argumento dos internacionalistas quanto à constitucionalidade material perdeu o sentido, pois:

Apesar da interessante argumentação proposta por essa tese [a internacionalista], parece que a discussão em torno do status constitucional dos tratados de direitos humanos foi, de certa forma, esvaziada pela promulgação da Emenda Constitucional 45/2004 [...]. Em termos práticos trata-se de uma declaração eloquente de que os tratados já ratificados pelo Brasil, anteriormente à reforma constitucional, e não submetidos ao processo legislativo especial de aprovação no Congresso Nacional, não podem ser comparados às normas constitucionais.

Ao revés, o antigo Ministro da Suprema Corte, José Francisco REZEK (2010, pp. 104-105), argumenta que:

[...] é sensato crer ao promulgar este parágrafo, na Emenda Constitucional 45 , de 8 de dezembro de 2004, sem nenhuma ressalva abjuratória dos tratados sobre direitos humanos outrora concluídos mediante processo simples, o Congresso constituinte os elevou à categoria dos tratados de nível constitucional. Essa é uma equação jurídica da mesma natureza daquela que explica que nosso Código Tributário, promulgado a seu tempo como lei ordinária, tenha-se promovido a lei complementar à Constituição desde o momento em que a carta disse que as normas gerais de direito tributário deveriam estar expressas em diplomas dessa estatura.

Surge assim, novamente, um impasse. Por um lado, a alegação de propositalidade por parte dos constitucionalistas, que levaria a dizer que todos os tratados anteriores a EC 45 continuam a ser infraconstitucionais (seja na modalidade supralegal, como entende hoje o STF, ou ordinária); do outro, a arguição dos internacionalistas de recepção formal dos tratados, através da equação postulada por Rezek. Para a solução do dilema, faz-se mister a análise do $\S 4^{\circ}$, do art. $5^{\circ}$, da Constituição.

\subsection{O Argumento Hermenêutico: análise do $\S^{\circ}$, do art. $5^{\circ}$}

Para a solução do intrincado problema do status dos tratados de direitos humanos anteriores à EC 45, convêm tecer algumas considerações sobre o Tribunal Penal Internacional, objeto do art. $5^{\circ}, \S 4^{\circ}$, da Constituição. 
A criação de um Tribunal Penal Internacional permanente significou, historicamente, o início de uma terceira fase na história do Direito Penal Internacional (ALMEIDA, 2012, pp. 611-612), imediatamente subsequente às fases dos Tribunais Penais Internacionais ad hoc de Nurembergue e Tóquio ( $1^{\mathrm{a}}$ fase) e da Iugoslávia e Ruanda ( $2^{\mathrm{a}}$ fase). O motivou as nações a pensarem em manter permanentemente uma Corte Penal que tratasse dos crimes de genocídio, contra a humanidade, de guerra e agressão (arts. $5^{\circ}$ e seguintes do Estatuto de Roma), seria a difundida intolerância quanto aos tribunais penais ad hoc, pois tal circunstância atinente à existência das cortes desobedeceria o princípio do juízo natural, um dos pilares do direito penal e do direito processual penal ${ }^{23}$.Some-se a isso o fato de que, historicamente, quando mais se era necessário uma resposta dos judiciários nacionais aos crimes atrozes que estados e governos perpetravam contra seus povos, a ideologia de alguns magistrados, é preciso reconhecer, tornou-se instrumento de cegueira propositada para com a justiça, dificultando ou até mesmo impedindo que culpados fossem responsabilizados por seus atos. Nesse sentido, as palavras do ex-presidente do TPI, Philippe KIRSCH (2007, p. 540):

Naturally, like any other crimes, punishment for grave breaches of the Geneva Conventions or for violations of the Genocide Convention or the customary law of war crimes and crimes against humanity depended primarily on national courts. The problem is that it is precisely when the most serious crimes were committed that national courts were least willing or able to act because of widespread or systematic violence or because of involvement of agents of the State in the commission of crimes. If you look at the past to the best known historical events of that kind-Nazi Germany, Rwanda, the former Yugoslavia, Cambodia - the governments themselves or their agents were involved in the commission of those crimes.

Enfatizada tal premissa, podemos compreender quão profundo e extraordinário foi para o Brasil expressar em sua constituição referência ao Tribunal Penal Internacional através da Emenda da Reforma do Judiciário: é

\footnotetext{
${ }^{23}$ Retornando ao tema da soberania, a existência de uma lei penal não plenamente nacional que seja vigente e eficaz em um estado soberano é prova concreta da não mais tolerância do argumento de soberania absoluta, pois no dizer de Guillermo Julio FIERRO (2007, p. 1) "[u]na de las formas más puras en que se expresa la soberania de um Estado reside em la facultad que este tiene de prohibir ciertas acciones o imponer otras, e infligir a quiene transgredan esas prohibiciones o mandatos una sancción penal". Em suma: a lei penal internacional demonstra a relativização da soberania.
} 
um retumbante recado às nações de que o estado brasileiro não se coadunará com os mais terríveis crimes, e seus juízes estão obrigados a obedecer esta realidade.

Como vimos, a inclusão do texto do $\S 4^{\circ}$, ao art. $5^{\circ}$, da CF, “O Brasil se submete à jurisdição de Tribunal Penal Internacional a cuja criação tenha manifestado adesão”, se deu pela Emenda Aglutinativa n 20, quando da votação da PEC 96/92 na Câmara dos Deputados. O Congresso Nacional, por meio do DL 112/2002, e o Executivo Federal, através do Decreto 4338/ 02, já haviam dado ao Estatuto de Roma (tratado que criou o TPI) natureza de lei ordinária dois anos antes da promulgação da Emenda 45, sendo assim óbvio que o referido tratado não passou pelo rito de emenda, somente previsto para a recepção de tratados de direitos humanos no biênio subsequente a sua aprovação.

Assim, seria coerente o raciocínio que objetasse que o Estatuto do TPI não seria uma norma constitucional, mesmo estando sua jurisdição prevista na Constituição. Não obstante, esse questionamento não tem razão de existir, pois o Estatuto de Roma, em seu art. 12, n” 1, esclarece que "O Estado que se torne Parte no presente Estatuto, aceitará a jurisdição do Tribunal relativamente aos crimes a que se refere o artigo $5^{\circ}$ ". Com efeito, quando o legislador brasileiro, sabendo da expressa necessidade de aceitação da jurisdição do TPI para validar a incorporação do Brasil ao Tratado de Roma, deu o seu consentimento não uma, mas duas vezes (sendo que nesta segunda vez houve um consentimento de hierarquia constitucional), deu lugar a uma constitucionalização ${ }^{24}$ não só da jurisdição do Tribunal, mas também do Estatuto que o criou, pois a jurisdição deve ser exercida relativamente aos crimes previstos no artigo $5^{\circ}$ do Estatuto, aprovado, anteriormente à EC 45, segundo procedimento de lei ordinária. Consolidada tal premissa não cabe afirmar que o Estatuto é infraconstitucional (SANTOS, 2013, p. 121).

Cientes disso, o argumento do silêncio eloquente aventado pelo Ministro Gilmar Mendes parece ser mais razoável do que o argumento do tempus regit actum de Francisco Rezek, pois como há um modelo que foi seguido pelo constituinte reformador, e este modelo do direito comparado expressamente dá a algumas convenções de direitos humanos a hierarquia constitucional, é realmente notório o fato do constituinte não ter se manifestado sobre qualquer

${ }^{24}$ Essa constitucionalização é de ordem formal, pois o art. $5^{\circ}, \S 4^{\circ}$, da CF cominado com o art. $12, \mathrm{n}^{\circ}$ 1 do Estatuto deu aos crimes previstos no Tratado um nível constitucional stricto sensu. 
tratado previamente incorporado ao ordenamento interno, exceto, por via indireta, ao Estatuto de Roma ${ }^{25}$.

\subsection{A "Supralegalidade" das Convenções sobre Direitos Humanos Anteriores à EC 45}

Acolher as razões do Ministro Gilmar Mendes, implica, necessariamente, na aceitação da tese supralegalista dos tratados anteriores à EC 45, que hoje se consolidou no STF? Benedito VICENTE SOBRINHO (2013, p. 58), ao comentar os precedentes jurisprudenciais e a edição da Súmula Vinculante 25, que levaram ao esvaziamento de conteúdo normativo do inciso LXVII, do art. $5^{\circ}$, da $\mathrm{CF}$, recorda que:

A Corte fez opção pela supralegalidade por entender-se diante do dilema: os tratados de direitos humanos não poderiam afrontar a supremacia da Constituição, mas considerá-los no nível da legislação ordinária; seria subestimar o seu valor especial na sistemática de proteção dos direitos da pessoa humana.

Como efeito, como temos afirmado, a prevalência da cogente dignidade dos homens deve se tornar o ponto gravitacional dos posicionamentos que pretendem solucionar a questão; sendo assim, mesmo que formalestruturalmente se possa e deva criticar possíveis lacunas na tese da supralegalidade, sua adoção deve ser considerada como um importante e belo passo para a valorização do direito internacional dos direitos humanos no âmbito jurídico interno, não devendo assim ser descartada sem um rígido critério. Posto isso, vejamos alguns argumentos que se colocam no caminho da tese da supralegalidade.

Smidt SIMON (2013, p. 109) faz a seguinte objeção: se os direitos individuais são cláusulas pétreas ( $\operatorname{art} .60, \S 4^{\circ}, \mathrm{CF}$ ), poderia um tratado de direitos humanos, considerado como norma supralegal, ser retirado do ordenamento

\footnotetext{
${ }^{25}$ Em outras linhas: a problemática envolvendo as convenções sobre direitos humanos anteriores à EC 45, parece encontrar solução ao se somar às justificativas apresentadas pelo constituinte reformador com o fato do Estatuto de Roma exigir dos estados-partes expressa submissão à jurisdição da Corte para a validação do Estatuto no âmbito interno; como no caso brasileiro isso ocorreu através de Emenda Constitucional, é plausível dizer que mesmo não tendo o Estatuto de Roma passado pelo procedimento do art. $5^{\circ}, \S 3^{\circ}$, ele já é norma constitucional e, por conseguinte, houve sim uma convenção sobre direitos humanos que recebeu da EC 45 o status de norma constitucional.
} 
por Emenda? Ou ainda: seria possível denunciá-lo? ${ }^{26}$ Se a resposta para tais questionamentos for "não", forçosamente concluímos que a posição acolhida pelo Supremo Tribunal Federal é completamente ineficaz para ampliar o âmbito de proteção dos direitos humanos e fundamentais. VICENTE SOBRINHO (2013, p. 59) vai mais além e ataca os fundamentos da decisão do STF quando da decisão sobre a controvérsia do depositário infiel: o alegado efeito paralisante do art. $7^{\circ}, \mathrm{n}^{\circ} 7$, da Convenção Americana, quando confrontado pelo inciso LXVII, do art. $5^{\circ}$, demonstra que a infraconstitucionalidade especial dos tratados de direitos humanos anteriores à EC 45 tem exatamente os mesmos efeitos práticos do que a requerida hierarquia constitucional. Se a Constituição continua a ter sua supremacia inquestionada, o disposto na convenção deveria ser declarado inconstitucional e o STF não poderia, por coerência, ter alterado sua jurisprudência.

Em razão destes e de outros argumentos que mesmo dentre os constitucionalista há quem prefira a posição internacionalista da substancialidade constitucional dos tratados internacionais de direitos humanos, que, por conseguinte, admite a existência do bloco de constitucionalidade que compreenderia todas as convenções sobre direitos humanos aprovadas anteriormente, com procedimento de leis ordinárias.

Tais objeções poderiam ser coerentemente respondidas no seguinte sentido: 1) sim, é possível a retirada do ordenamento de um tratado internacional de direitos humanos que não tenha sido incorporado por procedimento de emenda, salvo a Convenção Americana, por força da Súmula Vinculante $25^{27}$. Isso desde que seja utilizado o caminho delineado pelo constituinte originário (denúncia). Porque, como vimos, ao que parece, somente o Estatuto de Roma foi elevado pela EC 45 à posição hierárquica constitucional; 2) parece-nos que a decisão do Pretório Excelso foi mais pautada pela equidade que por uma adequação à mens legis. Contudo, observa-se que também era intenção da EC 45 permitir a construção de uma renovada jurisprudência da Altíssima Corte, inclusive no tocante à posição hierárquica dos tratados internacionais, de modo

\footnotetext{
${ }^{26}$ Valério MAZZUOLI (2005, p. 327) era da opinião que a denúncia seria teoricamente possível, mas ineficaz, porquanto como a norma do tratado teria natureza constitucional, ela também era, automática e substancialmente, cláusula pétrea.

${ }^{27}$ Explicamos: com a edição da Súmula Vinculante 25, a denúncia da Convenção Americana de Direitos Humanos se tornou inconstitucional, porquanto o efeito vinculante erga omnes impede que a Administração denuncie o tratado fundamento normativo para a edição da súmula. Logo, como a Convenção Americana foi utilizada como parâmetro normativo para a decretação de uma inconstitucionalidade pelo Supremo Tribunal Federal, ela sim se tornou uma norma materialmente constitucional.
} 
que não nos parece existir aqui um caso de ativismo ${ }^{28}$. Todavia, em razão dos princípios da concordância prática e da harmonização, a coerência interna da decisão do STF depende de que a Convenção Americana seja considerada uma norma que materialmente reformou a Constituição.

\subsection{Os Efeitos Práticos da Equivalência de Emenda e a Hierarquia do DL 186/08}

Do ponto de vista teorético, a atribuição de peso de emenda constitucional a um tratado de direitos humanos demonstra que no âmbito interno nos aproximamos cada vez mais da tese do "sincretismo constitucional", que admite a existência, em ambos âmbitos normativos (nacional e internacional), de verdades incompletas que precisam ser mutuamente ajudadas, substituindo as teorias de concorrência por teorias de colaboração entre o direito constitucional e o direito internacional:

A concepção que atribui ao Estado uma autoridade ilimitada, [...] não é somente um erro pernicioso à vida interna das nações, à sua prosperidade $\mathrm{e}$ ao maior incremento do seu bem-estar, mas prejudica também as relações entre os povos, rompendo a unidade da sociedade supernacional, tirando a base e o valor ao direito das gentes, abrindo caminho à violação dos direitos alheios e tornando difícil o acordo para a convivência pacífica. (PIO XII ${ }^{\circ}$ 52).

É inevitável pensar aqui no mal indizível suportado pela humanidade nas grandes guerras, fruto da percepção da soberania do estado como algo irrestringível, ilimitado. É neste diapasão que o direito internacional dos direitos humanos encontra sua legitimidade e força, pois diferentemente do que ocorre com o direito interno, o direito internacional incorporado não está sujeito ao brocado lex posterior derogat priori. Ao contrário, coexiste e complementa a lei do estado, agindo de modo subsidiário e ao mesmo tempo atuante:

\footnotetext{
${ }^{28}$ Em verdade, vemos com inquietação e cautela a moderna atuação do Judiciário como legislador, em decorrência de entendermos ser o império da lei a mais sagrada baliza do Estado Direito, que subordina os cidadãos e também os Três Poderes. O Judiciário não pode estar acima da lei, sob pena de destronar o Estado de Direito e a justiça: "[...] ao direito positivo, a lei escrita o contém e o institui, conferindo-lhe a força da autoridade. Eis por quê, se faz necessário que os julgamentos sejam proferidos de acordo com as leis escritas". (AQUINO, 2005, p. 93) [Sm Th II-II, q. 60, a. 5, res].
} 
[...] no plano interno a codificação produz um efeito excludente ou de substituição: a norma codificada é encarada como uma norma nova que substitui a anterior. Diferentemente, na ordem internacional deriva daquela operação um efeito inclusivo ou de coexistência: a norma codificada coexiste com a norma costumeira originária [...] (ALMEIDA, 2012, p. 609, grifado no original).

Fundado nesta premissa, analisemos por fim a hierarquia das convenções que são aprovadas pelo procedimento de emenda, nos termos do art. $5^{\circ}, \S 3^{\circ}$. Deveras, é notória a relativa conformidade na doutrina pátria em admitir que a convenção, aprovada através do procedimento do $\S 3^{\circ}$, se torna instrumento de derivação constitucional, pois todos os dispositivos da convenção que eventualmente sejam conflitantes com a Constituição geram uma inaplicabilidade destes últimos ${ }^{29}$. Na realidade, isso significa que a Emenda 45 verdadeiramente criou uma nova subespécie de poder derivado reformador: o poder constituinte reformador complementar ou sincrético.

Entendemos que com a promulgação do $\S 3^{\circ}$, do art. $5^{\circ}$, pela EC $45 / 04$, o poder derivado reformador foi subdividido em poder constituinte derivado reformador próprio ou comum (art. $60 \mathrm{da} \mathrm{CF}$ ) e poder constituinte derivado reformador complementar ou sincrético $\left(\operatorname{art} .5^{\circ}, \S 3^{\circ}\right.$ ). Isso porque nota-se, no caso deste último, uma manifestação praxiológica da relação de complementariedade que deve existir entre o direito interno e o "direito internacional constitucionalizado" (FASSBENDER, 1998, p. 529; DUPUY, 1997, p. 1), que denominamos de "sincretismo constitucional", a exigir um "controle de constitucionalidade conglobante”.(SILVA, 2014, pp. 131-135)

\footnotetext{
${ }^{29}$ A expressão "pessoa portadora de deficiência", presente na Constituição (arts. 7º, XXXI; art. 23, II; art. 24, XIV; art. 37, VIII; art. 203, IV e V; art. 208, III e IV; art. $227 \S 1^{\circ}$ II e $\S 2^{\circ}$; e art. 244), é um exemplo desse esvaziamento do texto: a expressão utilizada na Convenção, e que pela equivalência de emenda, tem poder para alterar o texto constitucional, é pessoa com deficiência, estando o Brasil obrigado a utilizá-la. Na realidade, através do $\S 3^{\circ}$, do art. $5^{\circ}$, o tratado se torna referência para o controle de constitucionalidade, diferente dos que não foram aprovados pelo procedimento, que podem ser nortes para o controle de convencionalidade, consistente num controle de legalidade qualificado, de uma norma convencional que, apesar de não ostentar a qualidade de norma constitucional, é hierarquicamente superior a lei ordinária. Podemos, por exemplo, realizar um controle de convencionalidade entre o Código Civil e o Estatuto da Criança e do Adolescente, que devem guardar conformidade com a Convenção sobre os Direitos das Crianças (norma supralegal). É o que já sustentamos em parecer (Caíque Tomaz Leite da SILVA, 2013, pp. 68-71). Isso no âmbito interno, pois, a rigor, o controle de legalidade de um instrumento internacional deve ser feito, a princípio, pelo órgão oficial do tratado, responsável por sua interpretação autêntica, independentemente da posição hierárquica que o tratado ocupe no âmbito interno dos estadosmembros. No caso da Convenção Americana, a Corte Interamericana de Direitos Humanos.
} 
Desse modo, as convenções equivalentes às Emendas Constitucionais permitem que se complemente e que se revise o texto constitucional à luz de um instrumento normativo internacional ao qual nós soberanamente aderimos, que seria, agora, por força da equivalência, internamente tutelado nos termos do art. $60, \S 4^{\circ}$, da $\mathrm{CF}$, reforçando, dessa maneira, a co-responsabilidade normativa do direito interno e do direito internacional, e a subsidiariedade na atuação jurisdicional internacional (Ibid., p. 138). Assim, todo e qualquer tratado de direitos humanos que passe pelo crivo do poder constituinte reformador sincrético tornar-se-á parte do núcleo imodificável da Constituição, sendo seu conteúdo indisponível ao poder de emenda (limite objetivo) ou denúncia (ineficaz no plano constitucional interno), havendo uma redefinição "di dimensione soggettive ed oggettive esistenti ed inoltre come espressione di autointegrazione ed eterointegrazione del sistema costituzionale" (PANEBIANCO, 2001, p. 124).

\section{CONSIDERAÇÕES FINAIS}

A despeito dos inúmeros problemas que ainda circundam a realização judicativa do direito, é inegável a positiva contribuição que a Emenda Constitucional $n^{\circ} 45$, de 8 de dezembro de 2004, oriunda da Proposta de Emenda à Constituição 96/1992, da Câmara dos Deputados, trouxe ao problema da interação entre o direito constitucional interno e o direito internacional constitucionalizado.

Acima da vaidade das pretensões doutrinárias, os direitos cogentes à dignidade humana devem ser o vértice da realização judicativa do direito, invalidando qualquer pretensão divergente, em qualquer segmento de realização do direito. Nesse sentido, o sincretismo constitucional permitido pelos parágrafos do artigo $5^{\circ}$, da $\mathrm{CF}$, contribuem para que a relação de freios e contrapesos seja instaurada, também, entre os âmbitos normativos interno e internacional.

Em razão das justificativas apresentadas pelos constituintes reformadores por ocasião da discussão e votação da PEC 96/92, conclui-se que a correta exegese dos $\S \S 3^{\circ}$ e $4^{\circ}$, introduzidos ao art. $5^{\circ}$, exige análise da disposição simétrica, e fonte de inspiração, encartada pela Constituição Argentina, e como ela conferiu hierarquia constitucional a algumas convenções de direitos humanos, há que se relevar a constitucionalização da jurisdição do Tribunal Penal Internacional, e, por conseguinte, o Estatuto de Roma. O silêncio do constituinte reformador quanto as outras convenções, permite aduzir com rigor científico que não cabe, portanto, estender a hierarquia constitucional à outras convenções que não tenham sido aprovadas de acordo com o quórum do art. $5^{\circ} \S 3^{\circ}$. 
A única convenção aprovada pelo procedimento anterior que não parece ser suscetível de denúncia, e que pode ser considerada como materialmente constitucional, é a Convenção Americana de Direitos Humanos, em decorrência da edição da Súmula Vinculante 25. Em regra, os tratados internacionais de direitos humanos anteriores à EC 45 não possuem a natureza de norma constitucional, as únicas exceções vigentes são o Estatuto de Roma (que cremos ser norma constitucional stricto sensu [formal]) e a Convenção Americana (que é norma constitucional lato sensu [material]).

Por fim, vimos que o $\S 3^{\circ}$, do art. $5^{\circ}$, subdividiu o poder constituinte reformador em comum e complementar ou sincrético. Este último eleva diretamente as convenções à condição de núcleo imodificável da Constituição, o que impede sua posterior supressão e derroga quaisquer disposições do ordenamento interno que estejam em contrário.

\section{REFERÊNCIAS}

ALEXY, Robert. Direitos humanos sem metafísica? In: ALEXY, R. Teoria Discursiva do Direito. Organização, tradução e estudo introdutório de Alexandre Travessoni Gomes Trivisonno. $1^{\mathrm{a}}$ ed. Rio de Janeiro: Forense, 2014;

ALMEIDA, Francisco António M. L. Ferreira de. Codificação e desenvolvimento progressivo do Direito internacional penal. In: Boletim da Faculdade de Direito. Vol. LXXXVIII. Tomo II. Universidade de Coimbra, 2012;

AQUINO, Santo Tomás de. Suma Teológica II-II. Questões 57- 122. V. 6. São Paulo: Ed. Loyolas, 2005;

ÁVILA, Humberto. Teoria dos princípios: da definição à aplicação dos princípios jurídicos. $13^{\mathrm{a}}$ ed. São Paulo: Malheiros, 2012;

BRASIL. Congresso Nacional. Câmara dos Deputados. Diário da Câmara dos Deputados, Brasília, ano 47, no 58, $1^{\circ}$ maio 1992, p. 7850 e 7851. Disponível em: $<$ http://imagem.camara.gov.br/Imagem/d/pdf/DCD01MAI 1992.pdf\#page=7>. Acesso em: 12 ago 2014. Justificativa da PEC 92/96;

. Congresso Nacional. Câmara dos Deputados. Diário da Câmara 
dos Deputados, Brasília, ano 49, no 183, 3 dez 1994, p. 14882. Disponível em: <http://imagem.camara.gov.br/Imagem/d/pdf/DCD03DEZ1994.pdf \#page $=7>$. Acesso em: 12 ago 2014. Propostas de Emenda à Constituição prejudicadas em face ao encerramento da Revisão Constitucional;

. Congresso Nacional. Câmara dos Deputados. Justificativa do $\S \S$ $3^{\circ}$ e $4^{\mathbf{o}}$ no art. $5^{\circ}$ da Constituição [mensagem pessoal]. Mensagem eletrônica recebida por <cadusindona@gmail.com> em 7 ago 2014. Protocolo: 3BB9103197186. E-mail de origem informa.cedi@camara.leg.br;

. Supremo Tribunal Federal. Ação Direta de Inconstitucionalidade no 939/7 DF. 1993. Rel. Min. Sydney Sanches. Disponível em: <http:// redir.stf.jus.br/paginadorpub/paginador.jsp?doc TP=AC\&docID=266590>. Acesso em: 18 ago 2014;

. Supremo Tribunal Federal. Habeas Corpus no 72.131-1/RJ. 1995. Rel. Min. Marco Aurélio. Disponível em: $<$ http://redir.stf.jus.br/paginadorpub/ paginador.jsp?docTP=AC\&docID=73573>. Acesso em: 18 ago 2014;

. Supremo Tribunal Federal. Recurso Extraordinário 349.703-1/ RS. 2008. Rel. Min. Gilmar Ferreira Mendes. Disponível em: <http:// redir.stf.jus.br/paginadorpub/paginador.jsp?docTP $=\mathrm{AC} \& \operatorname{docID}=595406$ $\& p g \mathrm{I}=1 \& \mathrm{pgF}=100000>$. Acesso: 21 ago. 2014 ;

BICHARA, Jahyr-Philippe. A Convenção relativa ao Estatuto dos Apátridas de 1954 e a sua aplicação pelo Estado brasileiro. In: Revista de Direito Constitucional e Internacional. RDU. Ano 21. V. 84, jul/set 2013;

DUPUY, Pierre-Marie. The Constitutional Dimension of the Charter of the United Nations Revisited. Max Planck Yearbook of United Nations Law, 1, 1997;

EMERIQUE, Lilian Balmant; GUERRA, Sidney. A incorporação dos tratados internacionais de direitos humanos na ordem jurídica brasileira. 2008. Rev. Jur. Pres.Rep. V. 10. No 90 Brasília, Ed. Esp. Abr./ maio. Disponível em: <http://portal.unitoledo.br/upload/usuarios/1442/avisos/ SidneyGuerra_Rev90.pdf_TRATADOS_DIREITOS_HUMANOS.pdf $>$. Acesso em: 12 ago 2014; 
FASSBENDER, Bardo. The United Nations Charter as Constitution of the International Community. Columbia Journal of Transnational Law, 37 , 1998;

FIERRO, Guillermo Julio. Ley penal y derecho internacional. Doctrina y jurisprudencia nacional y estranjera. $3^{\mathrm{a}}$ edición actualizada y ampliada. Buenos Aires: Editorial Astrea de Alfredo y Ricardo Depalma, 2007;

GALLEGO, Agustín González. Identidad y Globalización. Revista Portuguesa de Filosofia, $n^{\circ}$ 62, 2006.

HART, Herbert Lionel Adolphus. O conceito de direito. Tradução de Antônio de Oliveira Sette-Câmara. $1^{\mathrm{a}}$ ed. $2^{\mathrm{a}}$ tir. São Paulo: Martins Fontes, 2012;

HUMPHREY, John Peters. "The Universal Declaration of Human Rights: its History, Impact and Juridical Character". In: Human Rights: Thirty Years After the Universal Declaration. B. G. Ramcharan. The Hague, 1979;

JELLINEK, Georg. System der subjektiven öffentlichen Rechte. 2 ed. Tübingen: J. C. B. Mohr, 1905;

KIRSCH, Philippe. The role of the International Criminal Court in enforcing international law. 2007. Disponível em: $<$ http://

www.wcl.american.edu/journal/ilr/22/kirsch.pdf $>$. Acesso: 27 ago 2014;

LUÑO, António Enrique Pérez. Perspectivas e tendências atuais do Estado Constitucional. Tradução de José Luiz Bolzan de Morais e Valéria Ribas do Nascimento. Porto Alegre: Livraria do Advogado, 2012;

MAZZUOLI, Valerio de Oliveira. $O$ novo $§ 3^{\circ}$ do art. $5^{\circ}$ da Constituição e sua eficácia. In Revista da AJURIS. Ano XXXII. No 98 . Porto Alegre: AJURIS, 2005;

MELLO, Celso Albuquerque. O parágrafo $2^{\circ}$ do artigo $5^{\circ}$ da Constituição Federal. In: TORRES, Ricardo Lobo. Teoria dos direitos fundamentais. Rio de Janeiro: Renovar, 1999. 
MORAES, Alexandre de. Constituição do Brasil interpretada e legislação constitucional. $8^{\mathrm{a}}$ ed. São Paulo: Atlas, 2011;

PANEBIANCO, Mario. Iura humanitatis: diritti umane e "nuovi" diritti fondamentali. Revista Internazionale dei diritti dell'uomo. Ano XIV, 2001;

PIOVENSAN. Flávia. Reforma do Judiciário e Direitos Humanos. Caderno de Direito Constitucional da Escola da Magistratura do Tribunal Federal da 4a Região. 2006. Disponível em: <http://www.dhnet.org.br/ direitos/militantes/flaviapiovesan/piovesan_dh_direito_constitucional.pdf $>$. Acesso em 6 out 2015.

PIO XII, Papa. Carta Encíclica Summi Pontificatus. 1939. Disponível em: $<$ http://www.vatican.va/holy_father/pius_xii/encyclicals/documents/hf_pxii_enc_20101939_summi-pontificatus_po.html>.Acesso em: 26 ago 2014.

REALE, Miguel. Teoria do direito e do Estado. $5^{\text {a }}$ ed. rev. São Paulo: Saraiva; 2000;

REZEK, José Francisco. Direito internacional público: curso elementar. 12 ed. rev e atual. São Paulo: Saraiva, 2010;

SANTOS, Celso Araújo. Análise prática do Tribunal Penal Internacional (TPI): origem histórica, competência, procedimento, natureza das decisões e os delitos internacionais. In: Revista de Direito Constitucional e Internacional. Ano 21. Vol. 84. São Paulo: RT, jul/set 2013.

SÈVE, René. Les droits et libertes fondamentaux et la philosophie. In: Droits et libertés fondamentaux. $4^{\mathrm{a}}$ édition. Paris: Éditions Dallox, 1997;

SILVA, Caíque Thomaz Leite da. Espaço "longo" tempo "breve" Itinerários da metanarrativa constitucional: o constitucionalismo sincrético. In: Justiça do direito. V. 25. № 1. Passo Fundo: Ed Passo Fundo, jan/jun 2011;

. A tutela interconstitucional do processo. Revista dos Tribunais.

V. 941, Março 2014; 
. Ensaio sobre a possilbilidade jurídica da guarda alternada. Revista dos Tribunais. V. 930, Abril 2013;

SIMON, Henrique Smidt. A natureza jurídica dos tratados de direitos humanos: a incompatibilidade sistêmica da supralegalidade e a necessidade de revisão do entendimento do supremo tribunal federal. In: Direito, Estado e Sociedade. V. 42. Rio de Janeiro: Ed. Puc-Rio, 2013;

TRINDADE, Antônio Augusto Cançado. Direito internacional e direito interno: sua interação na proteção dos direitos humanos. In Instrumentos internacionais de proteção aos direitos humanos. São Paulo: Centro de estudos da Procuradoria Geral do Estado, 1991;

UN Doc. A/720/Add.1, 1968;

VARGAS, Angelo Miguel de Souza. O bloco de constitucionalidade: reconhecimento e conseqüências no Sistema Constitucional Brasileiro. 2007. Dissertação (Mestrado em Direito do Estado). Faculdade de Direito da Pontifícia Universidade Católica de São Paulo. Disponível em: $<$ http:// www.sapientia.pucsp.br/tde_busca/arquivo.php?codArquivo=5710> . Acesso em: 12 ago 2014;

VICENTE SOBRINHO, Benedito. A inadequada supralegalidade dos tratados internacionais de direitos humanos. In: SILVEIRA, Daniel Barile da (coordenador). A Corte Interamericana de Direitos Humanos e sua jurisprudência. Coleção Unitoledo. $1^{\mathrm{a}}$ ed. Birigui: Boreal Editora, 2013.

Artigo recebido em: 21/10/2015 Aprovado para publicação em: 21/10/2015

Como citar: SILVA, Caíque Tomaz Leite da Silva. OLIVEIRA, Carlos Eduardo Sindona de. O Décimo Aniversário da Emenda 45 e a Posição Hierárquica dos Tratados de Direitos Humanos. Revista do Direito Público. Londrina, v.11, n.1, p.137-162, jan/abr.2016. DOI: 10.5433/1980-511X.2016v11n1p137. ISSN: $1980-511 X$. 